\title{
Phenomenology of Communication of Generation Z in Pekanbaru
}

\author{
Tika Mutia ${ }^{1, a)}$ \\ ${ }^{1}$ Faculty of Dakwah and Communication, UIN Sultan Syarif Kasim, Riau \\ atikamutia@uin-suska.ac.id
}

DOI: https://doi.org/10.18196/ikm.111015

Article Info

Article history:

Received 13 March

2019

Revised 04 April 2019

Accepted 7 May 2019

\begin{abstract}
The Generation $\mathrm{Z}$ and its capability in following the latest technological developments create a new phenomenon, ranging from their lifestyle that so close with information and technology to the communication style; not to mention their domination in social media communication. Uniquely, they tend to believe that their lives in social media are more essential than in the real world. This study uses an interpretive paradigm with a qualitative approach. The research subject isGeneration $\mathrm{Z}$ in Pekanbaru while the object is the phenomenology of communication of Generation Z. The study finds two categorizations of Generation Z's selfrepresentation in Pekanbaru, namely: "The Influencer" and "The Followers." Furthermore, verbally, they often use informal language and slang and have difficulties in face-to-face communication. Nonverbally, they possess informal intonation, follow the latest fashion trends, and are expressive in social media.
\end{abstract}

Keywords: Generation Z; Phenomenology; Social Media.

\section{ABSTRAK}

Keberadaan Generasi $Z$ dan kelebihannya dalam mengikuti perkembangan teknologi terkini ternyata menciptakan fenomena baru. Mulai dari fenomena mengenai gaya hidup mereka yang sudah melek IT hingga gaya komunikasinya. Terlebih lagi, Generasi Z memang dikenal lebih mendominasi komunikasi melalui media sosial. Uniknya, mereka cenderung menganggap media social adalah segalagalanya dari pada dunia nyata. Penelitian ini menggunakan paradigma interpretif dengan pendekatan yang bersifat kualitatif. Subjek penelitian adalah Generasi $Z$ di kota Pekanbaru sedangkan objeknya adalah fenomenologi komunikasi generasi $Z$. Hasil penelitian ditemukan 2 kategorisasi Representasi Diri Generasi Z di kota Pekanbaru yakni : "Sang Influencer" dan "Sang Followers". Kemudian gaya komunikasi generasi $Z$ secara verbal, yakni mereka sering memakai bahasa tidak baku, sulit mengungkapkan maksud dan sering memakai istilah tertentu yang lebih dipahami oleh generasi Z lainnya. Sedangkan secara nonverbal, mereka memiliki intonasi berlebihan, penampilan sesuai tren terbaru dan ekspresif ketika tampil di dunia media sosial.

Kata kunci : Generasi Z; Fenomenologi; Media Sosial.

\section{INTRODUCTION}

The advent of Generation $\mathrm{Z}$ coupled with its uniqueness recently has grown to be a public concern, especially for those who come from previous generations, such as generation Y (millennial) and $\mathrm{X}$. It is the reason for which the numbers of research, journals, and articles trying to explore and define Generation Z' characteristics and potency is increasing. 
As cited from Entrepreneur, December 27, 2015, Generation Z or only Gen Z is the new generation who were born from the middle 1990s to date, meaning the oldest members from Gen $Z$ are still teenagers. They are the very generations who grew up in the middle of technological development; a time when types of the cell phone are transforming to be more cutting-edge, the scope of the internet availability is broader, and the accessibility of social media becomes easier. It is not surprising then if topics about Gen $\mathrm{Z}$ attract many experts from different fields, ranging from education, economics, politics, socials, to culture.

Gen $\mathrm{Z}$ and its capability in following the latest technological trend create new phenomena, starting from lifestyle until the communication style. Not to mention that Gen $\mathrm{Z}$ is also more dominant on social media communication. However, and this is the issue here, they tend to believe that social media is more important than the real world. Their timelines demonstrate it clearly as if social media is a must. It is different from the previous generations which had undergone limited internet access and should wait longer for print mass media for gaining the latest information. Gen Z' inclination on social media thus is deemed affecting their competencies in face-to-face interactions.

Mulyana and Rakhmat (2005) contended that one of the most significant reservations concerning Gen $\mathrm{Z}$ is their communicative competencies. The reason is that it is reasonable to imagine that individuals entering a new cultural environment will put up with many obstacles, including the mental one because they only adapt to their current surroundings (Mulyana and Rackhmat, 2005)

On the other hand, a phenomenology of communication provides a scientific approach to study communicative phenomena by giving pressure on the uniqueness of the observed people. With this in mind, studying communication patterns of Gen $\mathrm{Z}$ is compelling since, different from the previous generations who might still have offline time with their smartphones, it is not the case with Gen Z. In the age they are living, their borders between virtual and real life seem vanished. Gen Z is likely to use a smartphone and therefore online more often. Unfortunately, not all communicative interactions can run effectively by using smartphones.

Against that background, the context of the research is the unique communicative phenomenon of Gen Z. The study then aims to understand the communicative phenomenon of Generation $\mathrm{Z}$ in Pekanbaru using phenomenology as the optic. The researcher opines that research on the phenomenology of communication of Generation $\mathrm{Z}$ has not carried out too often nationally. Besides, the research also can be classified into a new study for communication program in UIN Suska Riau since the object matter is Generation Z, which is identic with the development of social media. Another identified research studying Generation $Z$ was a study conducted in 2016 by DiyahPuspitaRini, a student in UniversitasNegeri Yogyakarta (UNY). The study entitled "Pengaruh Karakter Generasi Z dan Peran Guru dalam pembelajaran terhadap Motivasi Belajar Akuntansi Siswa Kelas X Akuntansi SMK Negeri 1 Godean" (The effects of Generation Z characters and the roles of the teachers in learning process towards students motivation on studying accountancy for tenth-grade students in SMK Negeri 1 Godean).

\section{METHOD}

The research used an interpretative paradigm and qualitative approach. The research subject was Generation Z in Pekanbaru while the object was communicative phenomena of Generation Z. Qualitative research was a consistent approach for this investigation since this approach is reliable in investigating event occurring in society. It is conducted by focusing the researchers' perspective subjectively on subject-matter and interprets individuals' interpretations of the world (Moleong, 2001).

The data collection process was carried out through participative observation, interviews, documentation, and online tracking. Participative observation means observing objects of observation by living together in the same environment and experiencing their life-worlds (Bungin, 2007). Interviews were run for obtaining detailed information and conducted through direct with or without guidance question and answer sessions. Furthermore, interviewer and informant were required to have similar social lives in a significant period (Bungin, 2007). Documentation, on the other hand, was used for recording and documenting the information obtained.

After the pre-research stage, Pekanbaru was elected as the research location. The primary informants were Generation Z who were born from 1995 to 2000s and had been students, whether in high school or university or young entrepreneurs. The informants were decided through a purposive sampling method. In the research, ten informants were determined. Five persons represented Tampan 
district, and other 5 represent Pekanbaru districts. Tampan was chosen because its density level of Generation $\mathrm{Z}$ was high. It mostly happens since this district has two national universities, namely Universitas Riau and Universitas Islam Negeri Sultan SyarifKasim (UIN Suska) Riau and many secondary educations. Just as Tampan, Pekanbaru was also chosen because of the high distribution of the Generation Z, but it became more special because in this district many amenities for Generation $\mathrm{Z}$ to interact with each other were immensely available, ranging from malls, cafes, culinary, to the libraries.

Apart from the primary informants, the researcher performed triangulation by verifying the data with supported informants so that the data collected can be more accurate. The researcher used a purposive technique in the process of electing the informants to gain more diverse information from the people who are expert in the context of the research in question (Faisal, 1990).

The research was conducted from February to November 2018. Gathering the information from Generation $\mathrm{Z}$ in Pekanbaru was not an undemanding work to do since the gathering information process should not disturb their study time or other essentials activities. This approach followed what Creswell called as "gaining access and making reports" (Creswell, 1998). For most of the informants were students, the researcher attempted to establish decent relationships with them and endeavored to be their friends.

Data recorded were resulted from observation, field and social media; interviews with the informant; and social media tracking of Generation $\mathrm{Z}$. The recording processes were run through the following steps:

1. Recording the meeting using a tape recorder which can be put openly or secretly depending on the situations.

2. Paying attention to informant questions so that it can be openers to other items or be additional questions.

3. Tracking Generation $\mathrm{Z}$ online data, using photos and screenshot, from their social media activities which relate to their communicative phenomenon.

4. Data gathered from the tape, and video recorders were transcribed.

Qualitative data analysis was run interactively and continuously. "The activity performed in the analysis data is data reduction, data display, and conclusion drawing/verification" (Sugiyono, 2006). The first process was data analysis, and this process was commenced with collecting field notes and records which had been given labels, such as the name of the informants, dates, interviews places, and so on. Subsequently, data which had been gained from the recorders were transcribed. From that transcript, noticeable sentences, speech, and explanations were found. This first step also was conducted by transcribing data gathered from digital camera or Handycam. It was followed by noticing the most prominent identified themes from the interview data, digital camera, and Handycam. The second step, which was data display, was conducted by categorizing similar topic containing similar phenomena under one concept.

Furthermore, data validation in the research focused on auditing, and this process consisted of dependent auditing and assured auditing. As stated by Halper, "auditing process can follow these following steps: pre-entry, deciding auditable data, formal agreement, and data validation (Helpern in Moleong, 2007). Moleong adds that "in the pre-entry, some meetings should be done by the auditors and the auditees (in this case: the researcher) and finished it with a solid effort to continue, modify, and stop the audit process (Moleong, 2007).

The next step was deciding auditable data. Moleong argues that "in the deciding process, auditees' jobs are providing any notes needed and other available research materials as decided by the classifications" (Moleong, 2007).

In the research, the researcher also performed triangulation with the sources, meaning comparing and checking the degree of the reliability of the information gained through decisive tools in qualitative method (Moleong, 2001). The sources for obtaining information ranged from their closed-friends, lecturers, to activities on social media. 


\section{ANALYSIS}

\section{Self-representation of Generation $Z$ in Pekanbaru}

What makes Generation $\mathrm{Z}$ become a unique phenomenon is that they are growing in the very time of new massive communicative experience and technology and also dominate those trends. It is the result of their excessive use of smartphones, internet, and social media compared to other generation. This communicative experience enabled two categorizations of Generation Z's selfrepresentation that was discovered by the researcher, namely:

1. The Influencers

An influencer refers to an agent or the person. That is to say; an influencer means a person that can influence others. The criteria of Generation $\mathrm{Z}$ influencers are anyone who ceaselessly becomes creative using their smartphone, internet, and social media. For them, technological development was a big opportunity for inventing new innovative trend or other activities that can earn profits. As stated from one of the informants called Riri (23 years old) in the interview:

For me, the internet can fulfill any needs I want. I can learn a lot from the internet as well as acquiring new ideas to be creative on social media. Coincidently, I have a hobby in photography so that I can earn income actively through social media.

Likewise, the next informant called Irma (21 years old) picked social media as a tool for supporting their activities as university students. The following was the statement expressed by Irma:

I prefer using social media positively, such as making a video tutorial with my friends and looking for specific information for my college assignments. I rarely comment or witness any vents.

The second informant, according to researcher observation, frequently posted and shared some useful tips and tricks regarding social media, traveling, and studying, as well as vloged her daily college life. The following is one of them:

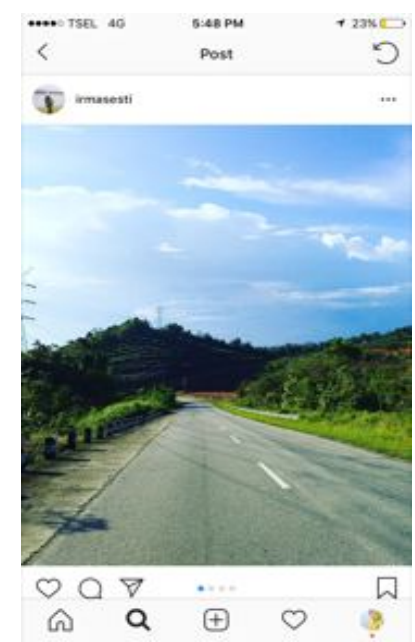

Figure 1. One of the informant' works on social media

The third informant was 21 years old, a college student, and came from Tampan district. Her social media name was @ermayani445. Erma said that she usually made tutorial videos in her YouTube account. Tutorial videos that she often uploaded, ranging from photography, graphic design, beauty, to fashion. The followings are pictures taken from online tracking of her social media account. 
Vol. 11 No. 1

May 2019

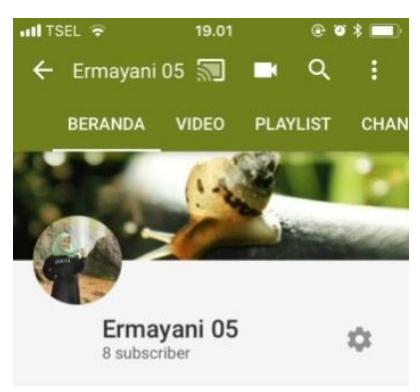

Upload

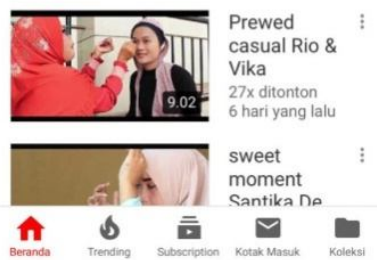

(a)

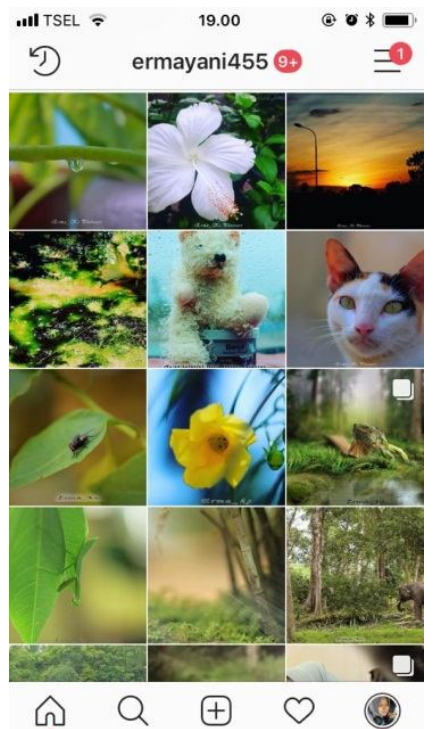

Figure 2. (a). Display of informant YouTube's account who loved to make tutorial make up (b). Feeds of informant social media that had photography themes.

2. The followers

The second category of self-representation of Generation $\mathrm{Z}$ in Pekanbaru is a title called "the followers," meaning some Generation $\mathrm{Z}$ that merely follow other Gen $\mathrm{Z}$ in term of social media communication. The observation showed that this category of Generation $Z$ communicated on social media for having fun. Indeed, some of them used social media to expose their personal lives and stories, such as family problems or personal vent. Up to a point, they utilized social media for discussing and having conversations about inappropriate and unnecessary topics. Also, this category of Generation $\mathrm{Z}$ was eager to upload pictures and videos without a caption and with unclear intentions for which those were uploaded. It can be seen from online tracking one of the informants.

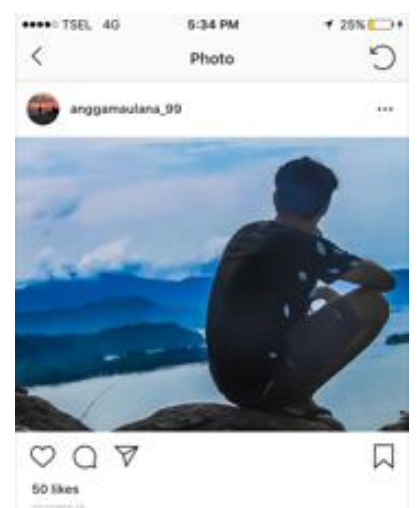

Figure 3. One of the "follower" post, without caption.

The picture above shows one of the informants who were Generation $\mathrm{Z}$ that included in the category of followers. The informant uploaded one image without mentioning or explaining anything, or on social media term, without caption. Picture without a caption was also found in his other photos. Unlike the former, the next informant often uploaded photos or statements which raised people 
curiosity. Also, he believed that social media account was only a place to make a better selfie and narcissism.

\section{The Motive of Generation $\mathbf{Z}$}

There are some reasons which imposed Generation $\mathrm{Z}$ to always prioritize communication on social media to direct interaction. Some factors found were:

1. Self-existence

The generation $X$ loved to show their existence by following new communicative and technological development, in this case on social media. Generation $\mathrm{Z}$ tried to shows their dynamic self using platform which can be accessed 24 hours. That is to say, without wasting energy to meet with others, they already could communicate actively with anyone and almost anytime.

2. Friendhood

The dynamics of youngsters' friendhood expected Generation $\mathrm{Z}$ for following the latest trend. For example, using social media, such as Instagram, was more common and prevalent, as opposed to Facebook, which mostly dominated by generation $\mathrm{X}$ or older.

3. Additional income

Besides being a place for self-existence and finding a place in the community, they, especially the influencers, also used social media for earning more money. It can be run in many ways, ranging from vlogging, making a tutorial video on YouTube, or giving product endorsement on Instagram.

\section{Verbal and Non-Verbal Communication of Generation $\mathbf{Z}$}

Another striking finding is that Generation $\mathrm{Z}$ in Pekanbaru was more comfortable to communicate using social media, such as Whatsapp, Instagram, and YouTube, rather than other direct face-to-face methods. In effect, they suffered from incompetency in their communication since barely did they have skillful experience in non-verbal communication through body gesture, eye contacts, face expression, paralanguage, and other methods which can be interpreted directly by their interlocutors. Although that communicative experience can be experienced through video call, the sensations were still different. At one interview, one of the informants expressed that:

If allowed, I prefer and more comfortable to communicate through WhatsApp rather than meet and talk directly with other people. Even with older people, for instance, if I would like to ask something to a lecturer, I frequently feel reluctant in face-to-face meetings. WhatsApp first, then I will meet him if it is necessary.

Lack of experience in term of interpreting verbal communication that happened because they mostly rely on social media made them somewhat inadequate to talk directly (oral). Meeting with many people in an event even made them uncomfortable since they were likely to embrace privacy, live in their social media, take selfies without considering their surroundings, and even laugh by themselves while having a meal in a restaurant.

Furthermore, verbally, this generation tended to use informal language and having difficulties in expressing their intentions. They usually talked unusually and loved to abbreviate words and phrases. Non- verbally, Generation Z had muchslang. For example, rather than "yuk" (let us go), they chose "kuy" and rather than "iri (jealous), they spoke julid; not to mention "Cetar" meaning "luarbiasa" (amazing), "Mantul" meaning "mantapbetul" (excellent), spekta or spektakuler (spectacular), bae or saja (only), kepo meaning "ingintahu" (curious), japri meaning "jalurpribadi" (private message), and so on. It can be seen in this display on one WhatsApp group: 
Vol. 11 No. 1

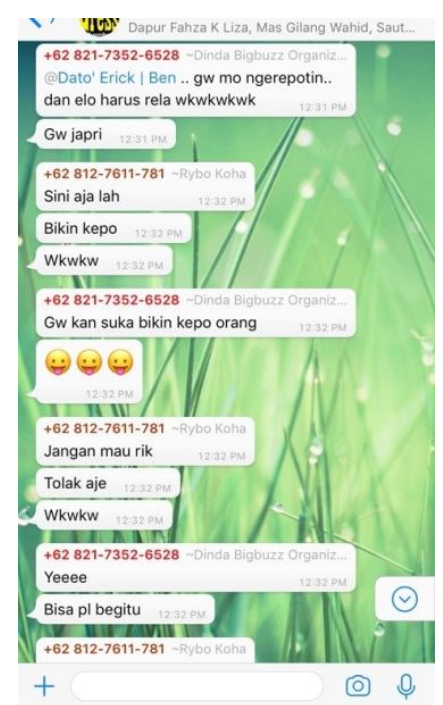

Figure 4. Screenshot of one of the Informants which use many new expressions

Another non-verbal point is that there were palpable differences in style between Generation $\mathrm{Z}$ and other older generation, namely Generation $\mathrm{Z}$ was more enthusiasts with current fashions. If public figures that came from the same age succeeded in making viral a type of fashion, then, Generation $\mathrm{Z}$ would likely to adopt those trend and lifestyle fast. They can absorb many products, from veil, shoes, and shades, to face expression while doing selfie. These pictures are some result of online tracking of some informant social media.

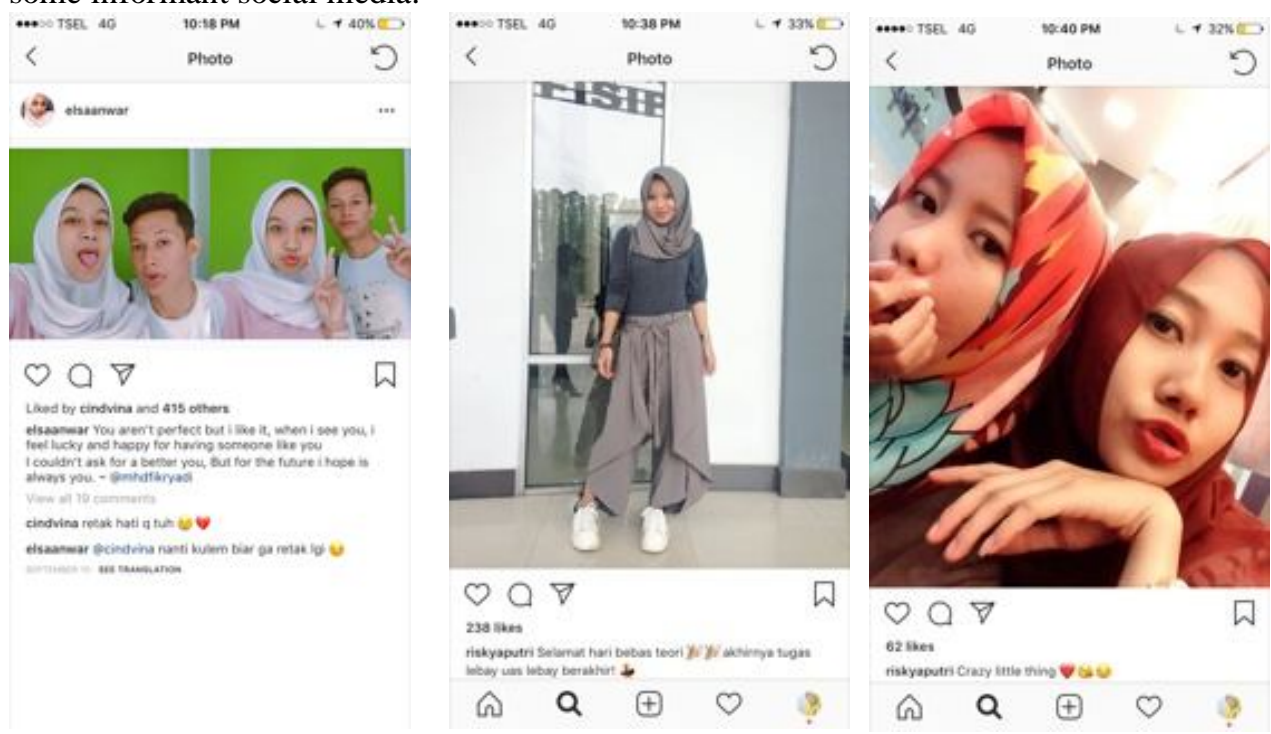

Figure 5. Display of the informant social media which express current non-verbal expression

Based on the explanation above, verbal and non-verbal communication of Generation $\mathrm{Z}$ in Pekanbaru can be reflected using this model: 


\section{6}

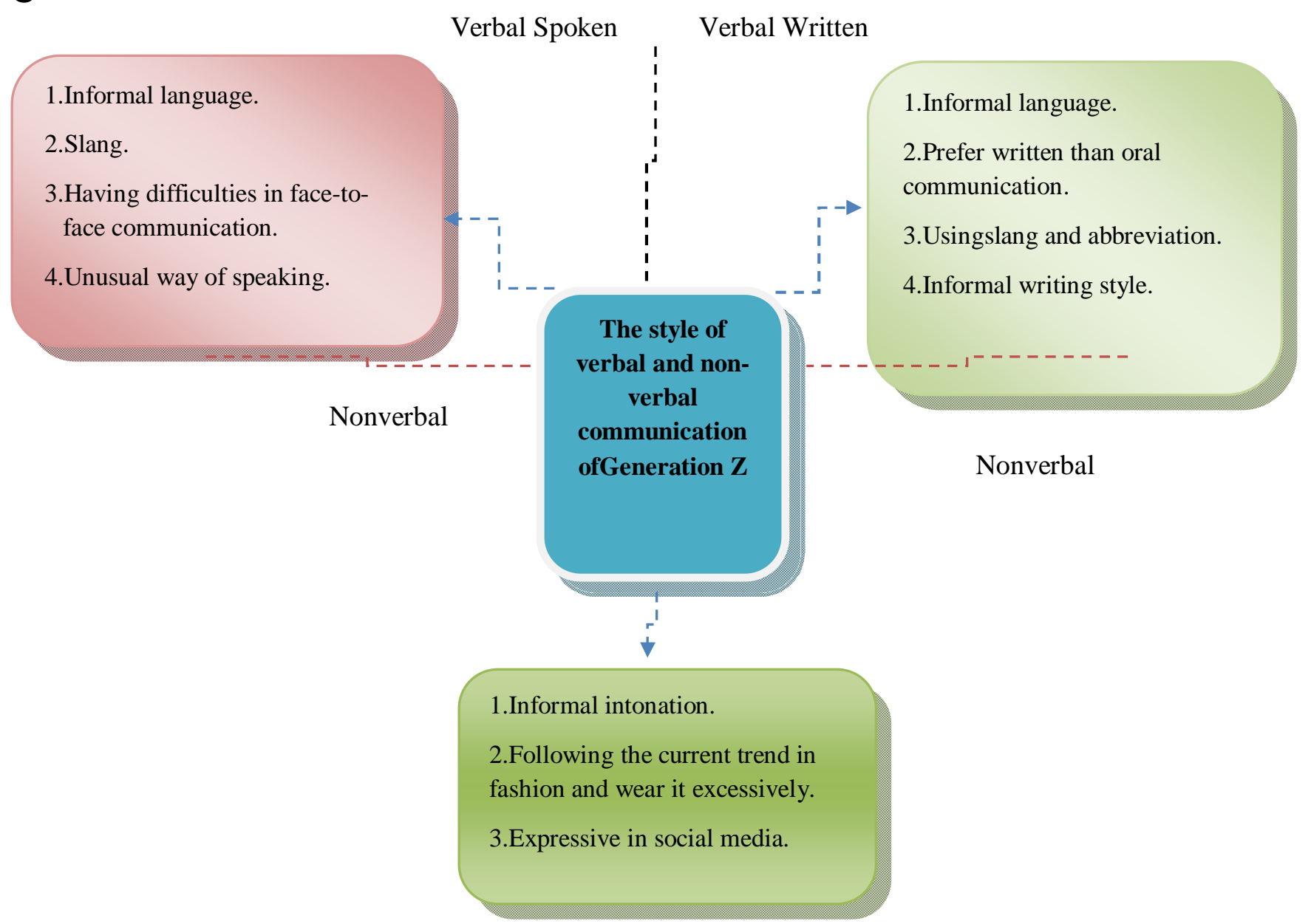

Figure 6. Model of verbal and non-verbal communication pattern of Generation Z in Pekanbaru Source: Research report, 2018.

\section{CONCLUSION}

In conclusion, two categories of self-representation of Generation $\mathrm{Z}$ in Pekanbaruwere found.The first was influencers or Generation $Z$ who actively influenced others positively using their smartphones, internet, and social media. For them, technological development was an alluring opportunity for inventing and making new innovative works and trend to earn income. They mad a video blog (vlog), tutorial video, picture, and so on. On the other hand, the followers were Generation $\mathrm{Z}$ in Pekanbaru that opted to be followers of other Generation $\mathrm{Z}$ in communicating on social media. The result has demonstrated that this category only used social media for having fun. Some of them only used it for exposing their personal lives and story, such as family problems and vent. They believed that social media was a place for having conversations and giving comments about inappropriate and unnecessary trends.

Some prominent motives of Generation $\mathrm{Z}$ in Pekanbarustayed in their style of communication was self-existence, the form of friendhood, and additional income. The generation $Z$ was more comfortable to communicate using social media, such as WhatsApp, Instagram, and YouTube, rather than face to face interaction. Verbally, they often used informal language, slang, and had difficulties in face to face interaction. Non verbally, they spoke with different intonation, followed the latest fashion trend, and were expressive when appearing in social media. 


\section{REFERENCES}

Aichner,T,and F Jacob (2015), Measuring the Degree of Corporate Social Media Use, International Journal of Market Research, pp: 257-275.

Baran, Stanley J (2004), Introduction to Mass Communication: Media Literacy and Culture. New York:McGraw-Hill.

BBC.n.d.http://www.bbc.com/indonesia/dunia-37984020 (accessed February28, 2017)

BBC.n.d.http://www.bbc.com/indonesia/trensosial-38633448 (accessed February 28)

Beebe, Steven A. Beebe, Susan J. \&Reamond, Mark V. (1996), Interpersonal Communication Relating to others. USA: Allyn\& Bacon.

Berger, Charles R,Michael ERoloff, and David RRoskos-Ewoldsen (2014), Handbook Ilmu Komunikasi.Bandung, Nusa Media.

Bungin, Burhan (2007), Sosiologi Komunikasi:Teori, Paradigma, dan Diskursus Teknologi Komunikasi di Masyarakat, Jakarta, Kencana.

DeVito, Joseph A. (1997), Komunikasi Antar Manusia. Jakarta, Professional Books. , 2004. Interpersonal Communication Book. Long-man Inc : New York

Faisal, Sanapiah ,(1990), "Penelitian Kualitatif; Dasar-dasar dan Aplikasi”. Malang, Yayasan Asih, 1990.

Kantor Berita Antara.n.d. http://www.antaranews.com/berita/605475/presiden-jokowimasyarakat-penyaring-kabar-terbaik?utm_source=tangkalhoax\&utm_medium=fokus\&utm_campaign=news (accessed February28,2017).

Kriyantono,Rachmat (2014), Teknik Praktis Riset Komunikasi Disertai Contoh Praktis Riset Media, Public Relations, Advertising, Komunikasi Organisasi dan Komunikasi Pemasaran, Jakarta, Kencana.

Liliweri, Alo. (1994), Komunikasi Verbal dan Nonverbal, Bandung, Citra Aditya

Moloeng, Lexy (1989), Metodologi Penelitian Kualitatif, Bandung, Remaja Rosdakarya.

Mudjiyanto, Bambang (2016), Metode Penelitian Komunikasi Berbasis Internet. Jurnal Studi Komunikasi dan Media. pp; 259-267.

Mulyana, Deddy dan Jalaluddin Rakhmat, (2005), Komunikasi antar Budaya Panduan Berkomunikasi dengan Orang-Orang Berbeda Budaya. Bandung, Remaja Rosdakarya. -.,(2002) Ilmu Komunikasi Suatu Pengantar. Bandung, Remaja Rosdakarya.

Nasrullah, Rulli, (2014), Teori dan Riset Media Siber.Jakarta, Kencana.

Yusuf, Amuri, (2014), Metode Penelitian:Kuantitatif, Kualitatif dan Penelitian Gabungan, Jakarta, Kencana.

Other source:

MajalahTempo Edisi 4545 (2-8 Januari 2017).

Entrepreneur, Minggu, 27 Desember 2015.

Oxford Learners PocketDictionary(2001). 